\title{
Should Flexible Bronchoscopy be Routinely Performed in Aspiration Pneumonitis: Non Liquet
}

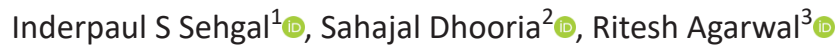 \\ Keywords: Aspiration pneumonia, Aspiration pneumonitis, Flexible bronchoscopy, Flexible fibreoptic bronchoscopy (FOB) in ICU. \\ Indian Journal of Critical Care Medicine (2021): 10.5005/jp-journals-10071-23743
}

Flexible bronchoscopy (FB) is a commonly used modality for diagnosing a variety of respiratory ailments. ${ }^{1}$ FB is used for performing several diagnostic procedures, including bronchoalveolar lavage (BAL), bronchial brushing, endobronchial biopsy (EBB), and transbronchial lung biopsy (TBLB). ${ }^{1-3}$ Several therapeutic procedures, including bronchial toileting, foreign body removal, stent placement, debulking of endobronchial tumors, and others can be performed using FB. ${ }^{3,4} \mathrm{FB}$ should generally be performed by experts who have been trained and are competent to handle complications associated with FB. To attain basic FB competency, one should have performed at least 100 supervised bronchoscopies and 25-50 flexible bronchoscopies per year independently to maintain competency. ${ }^{5}$

Apart from the indications mentioned above, FB is widely used in the management of critically ill patients. While FB is generally safe, critically ill patients are at a higher risk of complications. The common indications of FB in an intensive care unit are enumerated in Table $1 .{ }^{6}$ In this edition of IJCCM, Megahed et al. ${ }^{7}$ describe the use of FB in subjects with aspiration pneumonia. The authors randomized 76 mechanically ventilated subjects with aspiration pneumonitis to undergo early FB (within 24 hours after aspiration) or standard care. The authors demonstrated a reduction in progression to pneumonia in the intervention arm than the standard care arm. While the concept is interesting, the study has several limitations. The mean clinical pulmonary infection score (CPIS) was more than six in both the arms suggesting that most subjects in both the groups already had pneumonia at presentation. ${ }^{8}$ Most of the aspirations occurred outside the hospital and were not witnessed. It is also possible that there could be a difference in time to presentation to the hospital after aspiration. The authors employ a single used AMBU scope that could have significant cost implications in resource-constrained settings. The sample size calculation was done using mortality as an outcome, but the authors describe progression to pneumonia as the primary outcome (www.pactr.samrc.ac.za/201909915486179). The study thus is underpowered to detect a real difference in the progression of pneumonitis to pneumonia. Also, the authors have not utilized any objective criteria for diagnosing aspiration pneumonia or respiratory failure progression. Persistence of leucocytosis, fever, and infiltrates can also be encountered in aspiration pneumonitis. ${ }^{9}$ The demonstration of the bacterial pathogen (quantitative counts) would differentiate pneumonia from pneumonitis. ${ }^{10}$ However, there was no difference in the proportion of pathogens isolated in either arm. Notably, the authors could have used repeated measure analysis for demonstrating a difference in the SOFA score, lung

\footnotetext{
${ }^{1-3}$ Department of Pulmonary Medicine, Postgraduate Institute of Medical Education and Research, Chandigarh, India

Corresponding Author: Inderpaul S Sehgal, Department of Pulmonary Medicine, Postgraduate Institute of Medical Education and Research, Chandigarh, India, Phone: +91 1722746825, +91 1722756823, e-mail: ipdoc_2000@yahoo.com, inderpgi@outlook.com

How to cite this article: Sehgal IS, Dhooria S, Agarwal R. Should Flexible Bronchoscopy be Routinely Performed in Aspiration Pneumonitis: Non Liquet. Indian J Crit Care Med 2021;25(2):113-114.

Source of support: Nil

Conflict of interest: None
}

injury score, CPIS, and hypoxic index for a meaningful interpretation of results. ${ }^{11}$ Finally, the authors did not demonstrate any difference in mortality, ICU length of stay, or days spent on mechanical ventilation, possibly due to the small sample size. Also, whether FB guided bronchial toileting could reduce the antibiotic duration cannot be ascertained based on this trial's results. Nevertheless, the shortcomings of this study could be used to plan future trials using more objective criteria. We also require studies that would define the mechanism behind such a finding: whether the lavage removes an infective inoculum, whether it mainly acts by removing nidus of infection, or by just removing secretions and thus facilitating better ventilation.

In conclusion, currently, the role of FB in the ICU is limited to the removal of mucous plugs, blood clots, foreign bodies, or other aspirates that result in lobar or segmental collapse or respiratory failure.

Table 1: Indications of flexible bronchoscopy in an intensive care unit

\begin{tabular}{|c|c|}
\hline Diagnostic & Therapeutic or assistance \\
\hline $\begin{array}{l}\text { Airway inspection for diagnosing } \\
\text { airway foreign body or injury after } \\
\text { trauma }\end{array}$ & $\begin{array}{l}\text { Removal of secretions or blood } \\
\text { clots }\end{array}$ \\
\hline Hemoptysis & Removal of foreign body \\
\hline $\begin{array}{l}\text { Inspection of bronchial anasto- } \\
\text { mosis after lung transplantation }\end{array}$ & $\begin{array}{l}\text { Endotracheal intubation for } \\
\text { difficult intubations }\end{array}$ \\
\hline \multirow[t]{2}{*}{ Bronchoalveolar lavage } & $\begin{array}{l}\text { Placement of double-lumen } \\
\text { endotracheal tubes }\end{array}$ \\
\hline & Percutaneous tracheostomy \\
\hline
\end{tabular}




\section{OrCID}

Inderpaul S Sehgal (1) https://orcid.org/0000-0002-6505-6019

Sahajal Dhooria (1) https://orcid.org/0000-0003-3199-9163

Ritesh Agarwal @ https://orcid.org/0000-0003-2547-7668

\section{References}

1. Gupta AA, Sehgal IS, Dhooria S, Singh N, Aggarwal AN, Gupta D, et al. Indications for performing flexible bronchoscopy: trends over 34 years at a tertiary care hospital. Lung India 2015;32(3):211-215. DOI: 10.4103/0970-2113.156213.

2. Sehgal IS, Agarwal R, Gupta D. Conventional bronchoscopy techniques still are as efficient as newer techniques in the diagnosis of sarcoidosis. Sarcoidosis Vasc Diffuse Lung Dis 2016;32(4):378.

3. Sehgal IS, Dhooria S, Ram B, Singh N, Aggarwal AN, Gupta D, et al. Foreign Body inhalation in the adult population: experience of 25,998 bronchoscopies and systematic review of the literature. Respir Care 2015;60(10):1438-1448. DOI: 10.4187/respcare.03976.

4. Muthu V, Ram B, Sehgal IS, Dhooria S, Prasad KT, Bal A, et al. Predictors of severe bleeding during endobronchial biopsy: experience of 537 cases. J Bronchology Interv Pulmonol 2019;26(4):273-279. DOI: 10.1097/LBR.0000000000000593.
5. Mohan A, Madan K, Hadda V, Tiwari P, Mittal S, Guleria R, et al. Guidelines for diagnostic flexible bronchoscopy in adults: Joint Indian Chest Society/National College of chest physicians (I)/Indian association for bronchology recommendations. Lung India 2019;36(Supplement):S37S89. DOI: 10.4103/lungindia.lungindia_108_19.

6. Ergan B, Nava S. The use of bronchoscopy in critically ill patients: considerations and complications. Expert Rev Respir Med 2018;12(8):651-663. DOI: 10.1080/17476348.2018.1494576.

7. Megahed MM, EIMenshawy AM, Ibrahim AM. The use of early bronchoscopy in mechanically ventilated patients with aspiration pneumonitis. Indian J Crit Care Med 2021;25(2):146-152.

8. Pugin J, Auckenthaler R, Mili N, Janssens JP, Lew PD, Suter PM. Diagnosis of ventilator-associated pneumonia by bacteriologic analysis of bronchoscopic and nonbronchoscopic "blind" bronchoalveolar lavage fluid. Am Rev Respir Dis 1991;143(5 Pt 1):1121-1129. DOI: 10.1164/ajrccm/143.5_Pt_1.1121.

9. Mandell LA, Niederman MS. Aspiration pneumonia. N Engl J Med 2019;380(7):651-663. DOI: 10.1056/NEJMra1714562.

10. Neill S, Dean N. Aspiration pneumonia and pneumonitis: a spectrum of infectious/noninfectious diseases affecting the lung. Curr Opin Infect Dis 2019;32(2):152-157. DOI: 10.1097/QCO.0000000000000524.

11. Chan YH. Biostatistics 301A. Repeated measurement analysis (mixed models). Singapore Med J 2004;45(10):456-461. 